\title{
Mrs Thatcher's Macroeconomic Adventurism, 1979-1981, and its Political Consequences
}

\author{
Jim Tomlinson \\ Department of History, University of Dundee, Dundee, DD1 4HN, UK. \\ E-mail: j.d.tomlinson@dundee.ac.uk
}

Drawing on the influential analysis of Thatcherism by the late Jim Bulpitt, this paper seeks to do two things. First, to use the enquiries of the Treasury and Civil Service Committee of 1980 to underpin an account of economic policy-making in the initial period after 1979 which stresses the inadequacy of accounts which see policy as based upon a coherent, monetarist doctrine. Instead, it is argued that policy in this period is best described as 'adventurist', based on strikingly little analysis of its possible consequences. Second, this analysis is linked to the question of Conservative 'statecraft', and especially what Bulpitt called the 'political argument hegemony', which enabled the Conservatives to win the 1983 election despite mass unemployment. Here, it is argued, notions of economic 'decline' were crucial.

British Politics (2007) 2, 3-19. doi:10.1057/palgrave.bp.4200038

Keywords: Thatcher; economic policy; statecraft; declinism

\section{Introduction}

Many years ago Jim Bulpitt divined a thematic unity in analyses of the Thatcher government, with authors from a range of political positions concerned to explain something called "Thatcherism", and all holding to the belief that 'doctrines, especially monetarism, have had an important influence on key government policies and have contributed to the overall coherence of the government's operations'. But he noted a qualification to this theme in the writing of sceptics, 'who hold to one major alternative theme, namely that most accounts of these governments overstress their radical character and their consistent, even coherent purpose' (Bulpitt, 1986, 19-20). Bulpitt proposed an alternative approach to both of these, based upon a focus on Conservative statecraft, which he summarily defined as 'the art of winning elections and achieving some necessary degree of governing competence in office' (ibid., 21).

While Bulpitt's work has rightly stimulated some important thinking on Thatcherism (e.g. Gamble, 1988; Buller, 1999), its attempt to set a new agenda in approaches to the Thatcher governments has not been universally followed. Most prevalent has been a long-running debate, which explicitly or implicitly 
seeks to assess the degree of 'radicalism' of economic policies in this period. Broadly speaking, we may say that the more narrowly focussed literature has tended to qualify the story of this radicalism (e.g. Thain, 1985; Thain and Wright, 1995, Thompson, 1996), while broader accounts continue to see a fundamental change. As a result, it is probably true to say that the idea of that government pursuing coherent policies based on a coherent 'monetarist' doctrine is still highly influential. For example, it clearly underpins the approach of the recent second edition of his widely read survey of the Thatcher era by Eric Evans (2004).

The initial purpose of this article is to restate and reinforce the 'sceptical' case by looking in much more detail at the first two years of the Thatcher government, and the economic policies pursued in those years. This focus is driven by two considerations. One, on their accession to power in 1979 the Conservative government introduced policies which eventually led to the second worst slump of the 20th century (exceeded only by that of 1920-1921), and drove unemployment up, even on the conservative unemployment registration basis, from 1.3 to 2.4 million by 1981, peaking at 3.5 million in 1985 (Pliatzky 1982, 189; Middleton 1998, 340). Second, particularly through the enquiries of the Treasury and Civil Service Committee (TCSC) we have unusually detailed evidence on policy formation in this period, prior to the opening of the public records. However, having made the case for 'scepticism' in Bulpitt's sense, the paper reflects on what this episode suggests about the dimensions of Conservative 'statecraft' in these years.

In Eric Evans' account, the enormous rise in unemployment in the Thatcher years was an intended outcome, fully expected by the designers of those policies. He suggests that in attacking Labour's record on unemployment at the time of the 1979 election 'the Tories concealed the fact that they planned to see it rise much higher still', and further, that 'Howe and Thatcher were prepared to create an economic slump in order to kill inflation and resurrect the simple notion of 'proper money' for the benefit of the British people' (Evans, 2004, 17, 21). As Bulpitt notes, this kind of argument about the ideologically grounded and coherent basis of Thatcher's policies has been shared by a variety of political positions, and Evans here is particularly echoing earlier Marxist commentators, who had been even more explicit in arguing that the Thatcher government had deliberately engineered this level of unemployment to weaken the trade unions and destroy their bargaining power (for example see Aaronovitch and Smith, 1981, 369; Rowthorn, 1981, 4).

In contrast to this approach, this paper argues that far from being the implementation of a carefully designed policy to sacrifice employment on the altar of 'monetarism', the policies implemented in this period were poorly thought out, incoherent and pursued with little serious estimate of their likely consequences. They were the product of what can reasonably be called 
'adventurism' - a determination to pursue a radical policy shift with little serious analysis of what might follow for the level of economic activity and unemployment.

The first section of this paper provides further detail about the nature of the 1980s slump, and examines its causes. This is followed by a discussion of how policy was made in this period, and how it related to the rising tide of unemployment. The final section returns to the issue of 'statecraft' and offers some speculative conclusions about how the political consequences of Conservative economic policy may be understood.

\section{The Slump and its Causes}

While the fall in output in the early 1980s was substantial, employment fell much more sharply, generating a big improvement in the figures for labour productivity, an improvement which, of course, was the basis for a Thatcher 'miracle' (Walters, 1986: on this 'miracle' see Feinstein and Matthews, 1990). This large scale 'labour shedding' was probably accounted for by management recognition that there was likely to be no rapid recovery to justify hoarding labour, as so often happened in previous economic cycles. Unlike in the recession of the early 1990s, when recorded unemployment was much more evenly spread across the economy, that of the early 1980s was concentrated on the tradeable goods sector, which meant particularly manufacturing, and this in turn gave the unemployment a marked regional concentration (Townsend, 1983, chapter 3). However, a significant part of the more even spread of the 1990s was due to people having withdrawn from the labour market as a result of the 1980s slump, and so not showing up in official counts of unemployment; this indeed was one of the most important legacies of that earlier slump (Scott, 2004, 336-367). Less often emphasized in accounts of this period is how much the slump was concentrated on the private as opposed to the public sector, an ideological paradox not lost on Mrs Thatcher: 'private industry was faltering when we had been saying for years that only successful free enterprise could make a country wealthy' (Thatcher, 1993, 129).

The uneven impact of the recession was, due to its origin, felt largely in the export sector. At the time, and subsequently, Conservative Ministers and their apologists argued that the unemployment was due to the world recession, following on from the second OPEC price rise. However, this is not compatible with the evidence that the slump was both earlier and more severe in Britain than in other OECD countries. As Keegan points out (1984, 203), between 1979 and 1982: 'the total volume of the imports of the countries which comprise Britain's export markets grew by nearly 12 per cent, but our actual shipments to these markets fell by 5 per cent'. The OPEC price rise did have 
depressing effects (Dow, 1998, chapter 8), but the main cause of the depression in the export industries was the appreciation of the exchange rate.

The scale of this real appreciation in such a short time was extraordinary. Otmar Emminger, former President of the Bundesbank, told the Commons Select Committee on the Treasury in 1982 that it was 'by far the most excessive overvaluation which any major currency has experienced in recent monetary history' (cited in Keegan 1984, 171). There is no single way to measure such appreciations, but estimates of between 30 and 50 per cent give a sense of the scale of this event (Lawson, 1992, 58-63). This real appreciation was compounded by a nominal appreciation coupled to a British inflation rate which was comfortably higher than that in competitor countries. Contrary to all theories of the long run exchange rate under floating rates, the pound appreciated in nominal terms at a time when high inflation relative to competitors should have led to an offsetting depreciation.

This appreciation began after the stabilization of the currency which followed the IMF's imprimatur given to British economic policy after the 1976 visit (Burk and Cairncross, 1992). Thereafter the rate trended gently upwards, to a degree that in 1977 the Bank of England briefly intervened to try and hold the rate down (Stephens, 1996, 15). But the real shooting upwards came between the beginning of 1979 and January 1981, when the rate peaked (Neal, 2004, 296). Some part of this upward trend was due to the exploitation of North Sea oil, which, other things being equal, plainly strengthened Britain's balance of payments and therefore increased demand for sterling. Many supporters of Tory policy, then and since, have urged that this oil bonanza, rather than policy, was the main contributor to the appreciation. But this does not seem plausible; while oil can reasonably be argued to have pushed the rate on a gentle upward path from 1977 to 1978, it is hard to see how it can account for the spiral upwards of 1979 to 1981, which began during the 'Winter of Discontent' when it became widely expected that the Conservatives would win the forthcoming general election (for the economists' debate on this issue see Eltis and Sinclair, 1981). It is also undoubtedly true that there was a 'Carter effect', as the appreciation against the dollar was in part driven by the increasingly unfavourable view being taken by the markets of Carter's policies (Lawson, 1992, 60). But, again, this is far from the largest part of the story, which is one of the market 'over-reacting' to the general anti-inflation rhetoric of the Conservatives in combination with the higher interest rates they promised and, at least initially, delivered (Pliatzky 1982, 192-193).

\section{The Making of Policy}

The Conservative Manifesto of 1979 (Craig, 1990, 267-83), and the policy document on which it was based (Conservative Central Office, 1977) made little 
mention of the exchange rate. Labour was denounced in both documents for its policies leading to depreciation of the rate, but there was no argument to suggest that proposed Conservative anti-inflationary policies would do more than stabilize it. Both documents placed anti-inflationary policy at the centre of the Conservative agenda, and both were clear that this policy implied control of monetary growth. Beyond this, little was said about what the policy would look like, and how it would work. The manifesto, conditioned by the 'Winter of Discontent', was heavily focused on reducing the power of trade unions, although given the assumptions of monetarism about the purely monetary causes of inflation, this weakening of the unions bargaining power was not seen to have any direct effect on inflation.

The 1979 Manifesto famously denounced the Labour government for the rise in unemployment it had presided over. As noted earlier, it may be argued that this was wholly mendacious and that the Conservatives were privately preparing for a massive increase in unemployment to serve their own ends. But there is no evidence for this (Keegan, 1984, 111-112, 132). Certainly there had been questioning of the meaning of full employment on the Conservative Right in the mid-1970s (Joseph, 1975; Wood, 1975), and monetarist radicals expected some rise in unemployment to follow from their anti-inflationary monetary policies (Green, 2006, 66-8). But no one anticipated the scale of the disaster which would unfold.

The Conservative Manifesto attack on Labour's unemployment record and the 'Labour isn't Working' Conservative propaganda of 1979 reflected the belief, taken for granted amongst all the political class at that time, that low unemployment was dear to the heart of electorate, and that a party which was held responsible for mass unemployment would be punished at the polls - a view, it should be emphasized, that was certainly not undermined by the 1979 result (Butler and Kavanagh, 1980, 334). The Conservative line that government could not directly determine the level of unemployment was not at this time used as a reason to abandon the idea that they nevertheless should be held responsible for failings in this regard. The realization that general elections could be won against a background of mass unemployment only emerged in the wake of the result in 1983 (although, of course, such a conclusion could have been drawn from the Conservative electoral success of 1935: Green, 2006, 70).

The Conservative's initial period in office was dominated by the search for a way to reconcile the key promises to cut direct taxes while reining in government borrowing. These two could in principle be reconciled by big expenditure cuts, but it had been recognized in the 1977 policy document that such reductions would have to be phased in, so the initial policies would have to combine income tax cuts with some rise in indirect taxation. What emerged from initial discussions was a package consisting of spending cuts, reductions 
in both the top and standard rates of income tax, a virtual doubling of value added tax, and higher interest rates to improve the marketability of government debt. Howe (1994, 151), the Chancellor at the time, says the purchasers of gilts 'had in effect gone on strike' in the Autumn of 1979. On the monetary side, the underlying assumption of policy was that the growth of the money supply, measured as M3, was closely linked to the size of the Public Sector Borrowing Requirement (or, more precisely, that part of the PSBR not sold outside the banking system). The idea of such a link between fiscal and monetary aggregates was not invented by the Conservatives, but was part of Bank of England thinking from the mid-1970s (Keegan 1984, 117). What was new was the way the Conservatives elevated this link into the centrepiece of their economic strategy, eventually emerging in early 1980 with a Medium Term Financial Strategy (MTFS) which made the reduction in the rate of growth of both M3 and the PSBR the key targets. The core of the MTFS was the idea that governments could not directly affect real economic variables (especially growth and unemployment), but only financial variables, above all the inflation rate, by controlling the money supply, and public borrowing, which was seen as contributing to the growth of that supply. The Strategy, by giving targets for a four year period, was intended to change expectations, above all by suggesting that the targets would be inviolable; there would be no 'U-turns' (Thain, 1985).

A number of things must be said about the MTFS. First, it was not something the Conservatives had prepared before coming to office. While they had had intensive internal debates on the issues of taxation and public spending, and, of course, on trade union reform, they had devoted little attention to how monetary policy was to be conducted (Keegan, 1984, 124126; Oliver, 1997, chapter 4). Second, the stable relationship between the growth of M3 and the PSBR on which the strategy was predicated was a passing phase of the early/mid-1970s and was recognized as such by the economists whose ideas were most closely associated with the Conservative's adherence to monetarism. Most famously, Milton Friedman was strongly critical of the whole policy design, believing that the issues of fiscal stance and monetary growth were largely separate, and that attempting to control monetary growth by changing the size of the PSBR was quite the wrong way to go to achieve that aim (Friedman in TCSC, 1980, paras 55-61). Similar scepticism was expressed by Laidler, whose policy views in other respects were very close to those of the Conservatives (TCSC, 1980, paras 48-54). Indeed it is not clear that there was any prominent economist who believed in the stable relationship predicated by the MTFS. Sceptics seem even to have included Terry Burns, the newly appointed Chief Economic Adviser to the Treasury (Keegan, 1984, 140). Nevertheless, the Strategy, very much the product of Nigel Lawson, the Financial Secretary to the Treasury, served a clear political 
purpose by linking the traditional Conservative desire for fiscal 'prudence' with the new policy of monetary restraint. It did so, however, in a way that reflected a complete absence of understanding about key relationships in the economy.

This absence comes through in the Treasury's own evidence to the TCSC proceedings. This offers a broad defence of the MTFS framework, but stresses the 'uncertainty' about the transmission mechanism running from control of the money supply to a fall in inflation. Further, it acknowledges that monetary restraint may raise the exchange rate, but seems wholly insouciant about that rise, which at the time of the drafting of the evidence in June 1980 was already enormous (Treasury Evidence in TCSC, 1980, paras 11-13). Interestingly, the Bank of England evidence is much clearer on what was going on with the exchange rate, calculating a 40 per cent appreciation, measured by relative unit labour costs between 1976 and the middle of 1980 (TCSC, 1980, para 28).

As is well-known, the MTFS proved to have little relationship to what happened over the next few years, the M3 targets especially being significantly exceeded (Tomlinson, 1990, 324). But what is more important in the current context is how little that Strategy had to say about the key issue of the exchange rate appreciation. In fact, the rate was not mentioned at all in the first two versions of the Strategy, only making a belated appearance in 1982 when the peak of the appreciation was already past (Stephens, 1996, 16).

Another sign of the confusion in the core area of monetary policy was the public discussion of alternative approaches, most importantly monetary base control, an alternative to the focus on the PSBR outlined in a green (consultative) paper in 1980 - within only a few months of the announcement of the MTFS. Monetary base control followed the prescriptions of Friedman, but was ultimately rejected for the political reason that it was likely to destabilize interest rates, a crucial issue for the politically vital constituency of mortgagees (Howe, 1994, 186-70; Oliver, 1997, 77-81).

Central to the new approach to macroeconomic policy embedded in the MTFS was, of course, the idea that inflation can only be effectively controlled by controlling monetary growth. But interpretation of how this would work depended crucially on expectations, that is policy-makers' views on how economic agents would react to the government's policy pronouncements. Those who advocated money supply control were sharply divided between socalled 'gradualists' and 'new classicals' (Laidler in TCSC, 1980, paras 48-54; note that in this framework Friedman was also a gradualist). The former believed in 'adaptive' expectations, an approach which suggested that economic agents would react relatively slowly to a new policy regime, and therefore the tightening of monetary policy should be gradual, otherwise, before expectations adapted, the costs of the monetary tightening would be 
very severe for output and employment. Conversely, the new classical economists believed in 'rational' expectations, which basically meant that because agents had an incentive to correctly predict what the government policies foretold (i.e. that tight money would slow inflation) they would adapt their expectations immediately, and the result would be little output and employment loss. As Patrick Minford put it:

if you give people full information and they are convinced that you really mean what you say and this whole credibility problem is dealt with, then there is no reason at all in theory to expect that there would be cuts in output (TCSC, 1981b, Q.8).

The MTFS embodied a gradualist strategy, the medium term aspect intended to persuade economic agents that the government would stick to its policy over a period of years, and that therefore they should change their behaviour, not anticipate a 'U-turn'. But one of the key problems of the strategy was that no one had any idea how economic agents formed their expectations. The dispute between gradualists and rational expectations advocates was entirely theoretical. Thus, while the former might be thought wisely cautious, they actually had no more empirical knowledge than the latter. As the policy was predicated on changing expectations - on how people would understand a policy shift it could not be captured by any empirically grounded economic model, like that of the Treasury, because such models were precisely predicated on behavioural stability. Peter Middleton, defensively putting the Treasury's case, was forced to accept this point: 'I do not think you can expect any model to incorporate the structural changes in behaviour which the Government are trying to bring about' (Treasury Evidence, TCSC, 1981b, Q.286; also TCSC, 1981a, para 12).

The core of the government's policy was therefore aimed at achieving an expectational change, an ambition which was grounded in neither direct empirical evidence about what shaped expectations, nor even a formal empirical model which could form the starting point for an assessment of the likely effects of the new policy. On top of these massive uncertainties was the fact that the MTFS, as the main policy aimed at shaping these expectations, was only introduced in March 1980, 10 months after the Conservatives came to office. In that intervening period they had introduced the hike in indirect taxes which, of course, conveyed the clear expectation that prices would rise sharply as the tax was passed on into prices, which is precisely what did happen, with the increase in the RPI nearly doubling in the first year of the government. Thus, a tax policy decided in opposition, and to which both Mrs Thatcher and her Chancellor were resolutely committed, was pushed through despite being totally at odds with the expectational aspects of the macro-economic policy they were pursuing (Howe, 1994, 99). 
In his memoirs Howe grants that there was 'some justification' for Ian Gilmour's highly critical view that economic policy in this period was 'not that of the Cabinet but of a secretive monetarist clique' (ibid., 169). This 'clique', consisting of Thatcher, Howe, Joseph, Nott and Biffen, seems to have been particularly significant in these early months before the formulation of the MTFS at least gave some coherence to policy (ibid., 147; Campbell, 2003, 13). Their role arose in part from the still powerful position of the 'wets' in the Cabinet, and therefore the need, from Thatcher's point of view, for that body to be bypassed in the formulation of economic policy. What is striking about this group is how little economic knowledge they possessed; a notable exclusion was Nigel Lawson, by far the most knowledgeable Minister on economic issues. In particular, neither his contemporary responses to the TCSC inquiry nor his memoirs dispel the impression that Howe was out of his depth in discussing the economic issues faced in 1979-1981 (TCSC, 1981b, Qs.630-748, 793-871; Howe, 1994, passim).

In the early months of the new government the exchange rate appreciation was insouciantly neglected. The Bank of England and Treasury were baffled by what was happening, their theories of the rate being focused on the long-run equilibrium, which was plainly of little relevance to the current position (TCSC, 1981a, para 62). Increasing evidence that the rate was crucial to the recession led eventually in the summer of 1980 to Mrs Thatcher and her adviser, Alan Walters, calling for a report from the Swiss monetarist academic Jurg Niehans, who argued that the height of sterling was indeed a problem and was indicative, not of the effects of North Sea oil, but of how tight monetary policy really was, whatever the figures for M3 might be suggesting (Campbell, 2003, 81-82; Thatcher, 1993, 133-134). Within a few months this analysis legitimized cuts in interest rates, cuts which were probably crucial in the bottoming out of the recession in 1981, although unemployment continued to rise for several years.

\section{The Limits of Understanding}

The above summary narrative of the events of 1979-1981 raises a number of questions. First, if, as the evidence clearly shows, the authorities (politicians, the Treasury, the Bank of England) were surprised and baffled about the scale of the exchange rate appreciation, should they have been? As noted above, the size of this appreciation was unprecedentedly large, so it would be harsh to condemn them for not anticipating the precise scale. But the fact that changes in monetary stance could have large and unpredictable effects on exchange rates was something that should have been apparent to any interested observer at this time. After all, the Swiss franc had appreciated by 30 per cent in 1977/1978, and the yen by a similar amount between 1975 and 1978 (Tomlinson, 1990, 
315). While the authorities could reasonably be ignorant of the emerging theoretical literature on exchange rate 'overshooting' (Dornbusch, 1976), it is much harder to understand how they could display such ignorance about the recent gyrations in two major currencies.

The second question is why policy-making was so slow to get to grips with the appreciation issue once it became apparent that it was so important? Part of the answer is, as suggested above, the incoherence of policy, especially in the early months, when the (divergent) political imperatives of simultaneously reforming the tax regime and raising interest rates dominated any other actions. Coupled to this was the domination of policy by a small number of individuals who were ideologically committed to 'monetarism' but had little understanding of the economy. As early as August 1979 the government adviser, John Hoskyns, was writing that Howe and Thatcher were wrecking the economy 'out of sheer technical ignorance' (Hoskyns, 2000, 122). The, government, to re-emphasize, had not come to power with a well worked-out monetary policy, and one had to be devised 'on the hoof'. This was the background to the MTFS. But even after that was published in early 1980 the sense of incoherence was not allayed. Howe himself (1994, 191-192) describes policy-making at the time of the Autumn Statement of 1980 in the following terms: that it was 'not the product of any initially coherent strategic inspiration but rather the result of what looks in retrospect like a trudge through a seemingly endless series of multiple choice exam questions'.

Perhaps a third question to be posed is, how did the government try and make sense of the situation they had created? In the case of Howe there is an abiding sense of 'denial' in his comments on the period. Thus, he writes (1994, 190) that '[e]xchange rate and interest rates alike were, plainly, and as matter of common sense, too high for anything like comfort for industry'. This insouciance came at a time when the industrial sector was almost bankrupt, symbolized by ICI making a loss for the first time in its history (Keegan, 1984, $148,155)$. In a previous retrospective on these years, Howe had combined a complete ignoring of what happened to the exchange rate, with a defence of fixed exchange rates in general, and the ERM in particular, as the basis of economic stability (Howe, 1991).

At the time the Conservatives tried to argue that part of the problem causing mass unemployment was that wage setters had not adjusted rapidly enough to the new regime. Such an argument fitted with the focus on 'expectations' noted above, but in the context of the time the idea that wages could in any substantial measure compensate for the exchange rate appreciation was extraordinary (TCSC, 1981b Q.720). It would have involved a fall in money wages, on a scale not experienced since 1920-1922, at a time when inflation was still running in double figures. 
The answers to these questions reveal how extraordinary the policy-making regime was in this period. A small group of ideologues pursued an incoherent policy based on some vague notions about 'the money supply' and 'expectations', and ignored compelling recent empirical evidence about how disruptive to the economy such policy lurches could be because of their effects on the exchange rate. The result, to reiterate, was a recession and enormous levels of unemployment, with lasting effects on the welfare of many of those affected.

\section{Statecraft?}

So far this paper has sought to offer strong support for the 'sceptic' view about the incoherence of economic policy in the first years of the Thatcher government. But how does this episode relate to Bulpitt's framework of 'statecraft'? One simple answer might be to say that the election of 1983 vindicated government policy, and therefore provided one of the dimensions of statecraft: a 'winning electoral strategy' (Bulpitt, 1986, 22). Of course, such a view begs the question of how far the Conservative win in 1983 was based on economic policy. The evidence is clear that by that election the level of output in the economy had passed its nadir, even though unemployment was continuing to rise (Dow, 1998, chapter 8). But that economic recovery was based on a reversal of the tight money policy that had been pursued in the first eighteen months of the government. In the budget of March 1981 interest rates were reduced by two per cent. But because of all the focus on the tightness of the fiscal stance announced in the same budget, this policy loosening, which soon ended the pound's upward movement, was largely ignored - most notably by the 364 economists who famously protested against government policy in the same month as the budget (Wickham-Jones, 1992).

The Conservative win in 1983 was not solely based on economic issues. The split in the Labour Party and the success of the SDP was crucial in dividing the anti-Conservative vote, and delivering a huge Conservative majority on the back of a 44 per cent share of the vote. On the other hand, the 'Falklands factor' while commonly believed to have been important, appears not to be so (Sanders et al., 1987). This work suggests that revived 'personal economic expectations', based on tax cuts and a revival of economic activity were the key to the 1983 outcome.

But, even if output and incomes were rising, so, to reiterate was unemployment. Historically, failure on this policy would have been highly damaging to another of Bulpitt's dimensions of statecraft, 'governing competence' (Bulpitt, 1986, 22). How was this damaging outcome avoided? Here Bulpitt is surely right to say that it was above all the consequence of Conservative success in 'peripheralizing' and externalizing responsibility for 
economic failures. 'The unemployment problem, for example, was offloaded onto the unions, management, the world recession and the Reagan administration. In fact, no previous government had so comprehensively and systematically used its external weakness to bolster its domestic position' (ibid., 37). The perception the Conservatives had in 1979 that a government seen to be responsible for mass unemployment would be electorally punished was not wrong; having unintentionally caused such unemployment through adventurist policies, the government escaped the consequences by successfully displacing the blame. ${ }^{1}$

Finally, there is the further component of statecraft that Bulpitt calls 'party argument hegemony'. His definition is as follows:

This concerns a party achieving an easy predominance in the elite debate regarding political problems, policies and the general stance of government. Political argument is a much cruder and more comprehensive concept than ideology or theory. It refers more to a winning rhetoric in a variety of locations, winning because either the framework of the party's arguments becomes politically acceptable, or because its solutions to a particularly important problem seem more plausible than its opponents (Bulpitt 1986, 22).

Bulpitt backs up this definitional point by arguing that by 1983 the Conservatives had 'won the battle for political argument hegemony' (ibid., 38), but tells us little about what precisely this meant at the time. While political scientists like Bulpitt have been the innovators in analytic frameworks for understanding the Thatcher period, it is to historians perhaps that we can turn to understand the nature of the Thatcher 'political argument hegemony', above all in their placing of the notion of economic 'decline' at the very centre of that argument.

\section{Declinism and its Importance}

In an insightful essay, David Cannadine places Mrs Thatcher in a line of Conservative leaders (Joseph Chamberlain and Churchill being the previous cases) who each developed 'a coherent, doom-laden and apocalyptic vision part historical, part geopolitical, and part prescriptive' which saw Britain 'in decline' and themselves as the agents of reversal (Cannadine 1997, 262). In the case of Mrs Thatcher, she 'came to believe that the problems of the late 1970s, culminating in the miner's strike, stagflation and the Winter of Discontent, were merely the end point of a century-long period of national decline, mismanagement and retreat, of which the years since 1945 had been the worst of all' (Cannadine 276; also Eccleshall, 2000). Green (2006, 55-56, 71-72) makes a similar point about the importance of declinism, stressing decline's 
centrality to both her critique of Labour's policies and her promises of what a change of policy direction could achieve. Mrs Thatcher herself wrote that 'decline was the starting point for the policies of the 1980s: everything we wished to do had to fit into the overall strategy of reversing Britain's economic decline, for without an end to decline there was no hope of success for our other objectives' (Thatcher, 1993, 15).

The importance of this 'declinist' argument in the current context was that it provided a key basis for shifting blame for unemployment away from current policies and onto past errors; from current macroeconomic strategy to allegedly long-lived but previously hidden inefficiencies. In the 1983, Conservative Manifesto this is how the story of unemployment is told:

We have long been one of the least efficient and most over-manned of industrialised nations. We raised our own pay far more, and our output far less, than most of our competitors. Inevitably, this pushed prices up and drove countless customers to buy from other countries, forcing thousands of employers out of business and hundreds of thousands of workers out of jobs. At the same time, there has been a rapid shift of jobs from the old industries to the new, concentrated on services and the new technologies. Tragically, trade unions have often obstructed these changes. All too often this has delayed and reduced the new and better-paid jobs which could replace those that have been lost.

This characteristic Conservative position of the times shows an element of 'externalization' of responsibility for unemployment that Bulpitt neglects; perhaps, it might be suggested, this neglect arose because he, like so many others, was 'hegemonized' by notions of decline, and so failed to see it as a highly contingent, as well as highly successful, political argument, rather than a self evident fact about recent British history. ${ }^{2}$

What is surely striking is the hegemony of declinism in Britain from the 1950s, down to at least the 1990s, and its especial virulence in the 1970s and early 1980s. This virulence, of course, owed something to the economic condition of Britain in the mid-1970s, when inflation rose to an all-time high, public sector borrowing likewise, and there was a major exchange rate crisis. But while serious, the economic condition of Britain at this time did not merit the doomsday talk of many commentators (including Mrs Thatcher).

First, and most important, Britain suffered only a mild recession in 19731975; no more than a 'blip' in the long-run growth trend, and much less serious than the two slumps of 1979-1981 or 1990-1992. So the crisis proceeded in an economy, which for most of the time was continuing to grow. Second, the inflation problem, while serious, was short-lived and broadly in line with what occurred across Western Europe. While the British average annual inflation rate in the years 1974-1979 was 16.3 per cent, in Italy it was 16.9 per cent, in 
France 10.4; West Germany was the exception in its slow rate of 4.3 per cent (Artis and Cobham, 1991, 267). By 1979, the inflation peak had past, and the annual rate was down to around 8 per cent.

Similarly, balance of payments current account deficits were the norm in Western Europe in the wake of the first OPEC price rise, and again the deficit fell sharply after 1976 (Tomlinson, 2007). On the public finances, it is worth emphasizing that the problem was short-lived, and the combination of payments and budgetary deficits which undermined the value of the pound and notoriously brought a crisis visit from the IMF had already been reversed by the time officials from the Fund actually arrived in Britain. The budget deficit was falling from early 1976 as the new regime of cash limits on public spending began to bite; the IMF gave a seal of approval to a policy change which was already in place (Burk and Cairncross, 1992).

The 1970s was a bad decade for the British economy; but it did not see a major slump, and the crisis proved transitory. What turned 'a drama into a crisis' was a political discourse, which greatly exaggerated the extent to which short-term difficulties were the consequence of systemic failures. What Britain saw in the 1970s was a 'moral panic' about developments, which should now, with the benefit of hindsight, appear far less earth-shattering.

This panic, and the exaggerated declinism which underpinned it, was not just evident on the Right of the political spectrum. By the 1980s, it was subscribed to by almost every political force; having originated on the centreLeft, it had been rapidly taken up by Marxists, and later by the New Right, prior to its enthusiastic embrace by the Thatcherites (Tomlinson, 2000, chapters 3, 4, 6). As the journalist Peter Jenkins (himself a declinist of considerable rhetorical power) remarked, by the mid-1970s 'the notion of decline had become a commonplace among a dispirited intelligentsia' (Jenkins, 1996, 91), and this was true of the intelligentsia across the political spectrum.

\section{Conclusions}

This paper has sought to further understanding of two aspects of the Thatcher period. First, how policy-making in the earliest part of that period related to the extraordinary appreciation of the exchange rate, an appreciation which in turn largely explains the depth of the slump experienced in 1980 and 1981. It is argued that this appreciation was not a deliberate or expected outcome of policy, but the consequence of an 'adventurist' policy which pursued certain political ambitions with extraordinarily little concern for possible economic repercussions. A small coterie of Ministers by-passed the Cabinet and the usual formalities of Cabinet government, but also drew little on expert economic advice. The outcome was as surprising for the policy-makers as for everyone else. 
The other aspect addressed here is the Conservatives win in the 1983 general election, despite the unemployment caused by the exchange rate appreciation. Here, the argument is that the Conservatives were able to benefit from the economic revival from early 1982, while displacing responsibility for the mass unemployment, which continued to grow, onto an allegedly long-running and deep-seated problem of decline. The point to be emphasized is that this notion of decline was based on both a gross exaggeration of the seriousness of actual economic conditions in the 1970s, in combination with a highly problematic narrative that linked these conditions to a supposedly profound malaise in British society.

Further, these notions of 'decline' found resonance because by the mid1970s they had become the 'common-sense' of British political argument, across the political spectrum. In that important sense, Mrs Thatcher was a legatee of an already existing, cross-party hegemony of declinist notions, notions which, providentially, provided a politically powerful framework of argument for avoiding electoral punishment for the consequences of her adventurist policies.

\section{Acknowledgments}

The author is grateful to Roger Middleton and the referees for this journal for comments on an earlier version of this paper.

\section{Notes}

1 This argument is compatible with the finding that unemployment mattered to the electorate in 1983, but its rapid increase did not have much impact on perceptions of the Conservative government's economic competence, see Whiteley (1983). The relationship of unemployment to voting is evident at constituency and regional level, see Butler and Kavanagh (1984, 339-342).

2 For Bulpitt's adherence to declinism see Burnham and Bulpitt (1999). The collaboration involved in this article is itself a nice example of the cross-ideological adherence to declinist accounts of post-war Britain.

\section{References}

Aaronovitch, S. and Smith, R. (1981) The Political Economy of British Capitalism, London: McGraw Hill.

Artis, M. and Cobham, D. (1991) Labour's Economic Policies 1974-79, Manchester: Manchester University Press.

Buller, J. (1999) 'A critical appraisal of the statecraft interpretation', Public Administration 77(4): 691-712.

Bulpitt, J. (1986) 'The discipline of the new democracy: Mrs Thatcher's domestic statecraft', Political Studies 34(1): 19-39. 
Burk, K. and Cairncross, A. (1992) Goodbye Great Britain: the 1976 IMF Crisis, New Haven: Yale University Press.

Burnham, P. and Bulpitt, J. (1999) 'Operation Robot and the British political economy in the early 1950s the Politics of Market Strategies', Contemporary British History 13(1): 1-31.

Butler, D. and Kavanagh, D. (1980) The British General Election of 1979, London: Macmillan.

Butler, D. and Kavanagh, D. (1984) The British General Election of 1983, London: Macmillan.

Campbell, J. (2003) Margaret Thatcher Vol 2 The Iron Lady, London: Cape.

Cannadine, D. (1997) 'Apocalypse When? British Politicians and British 'decline in the Twentieth Century', in: P. Clarke and C. Trebilcock (eds.) Understanding Decline, Cambridge: Cambridge University Press.

Conservative Central Office (1977) The Right Approach to the Economy, London: CCO.

Craig, F.W.S. (1990) British General Election Manifestos 1959-1987, Aldershot: Dartmouth, pp. 267-283.

Dornbusch, R. (1976) 'Expectations and exchange rate dynamics', Journal of Political Economy 84: 1161-1174.

Dow, C. (1998) Major Recessions: Britain and the World, 1920-1995, Oxford: Oxford University Press.

Eccleshall, R. (2000) 'Party Ideology and National Decline', in: R. English and M. Kenny (eds.) Rethinking British Decline, Basingstoke: Palgrave, pp. 155-183.

Eltis, W. and Sinclair, P. (eds.) (1981) The Money Supply and the Exchange Rate, Oxford: Oxford University Press.

Evans, E. (2004) Thatcher and Thatcherism, (2nd edn.), London: Routledge.

Feinstein, C. and Matthews, R. (1990) 'The growth of output and productivity in the UK: the 1980s as a phase of the post-war period', National Institute Economic Review 133: 78-90.

Gamble, A. (1988) The Free Economy and The Strong State: the Politics of Thatcherism, Basingstoke: Macmillan.

Green, E.H.H. (2006) Thatcher, London: Hodder.

Hoskyns, J. (2000) Just in Time: Inside the Thatcher Revolution, London: Aurum.

Howe, G. (1991) 'The 364 economists: ten years on', Fiscal Studies 12(4): 92-107.

Howe, G. (1994) Conflict of Loyalty, London: Macmillan.

Jenkins, P. (1996) The Anatomy of Decline, London: Indigo.

Joseph, K. (1975) Reversing the Trend, London: Centre for Policy Studies.

Keegan, W. (1984) Mrs Thatcher's Economic Experiment, Harmondsworth: Penguin.

Lawson, N. (1992) The View from Number 11: Memoirs of a Tory Radical, London: Bantam.

Middleton, R. (1998) Charlatans or Saviours? Economists and The British economy from Marshall to Meade, Cheltenham: Elgar.

Neal, L. (2004) 'Impact of Europe', in: R. Floud and P. Johnson (eds.) The Cambridge Economic History of Modern Britain Vol. 3 Structural Change and Growth, 1939-2000, Cambridge: Cambridge University Press, pp. 267-298.

Oliver, M. (1997) Whatever Happened to Monetarism?, Aldershot: Ashgate.

Pliatzky, L. (1982) Getting and Spending: Public Expenditure, Employment and Inflation, Oxford: Blackwell.

Rowthorn, R. (1981) 'The politics of the alternative economic strategy', Marxism Today January: 4-10.

Sanders, D., Ward, H. and Marsh, D. (1987) 'Government popularity and the Falklands war: a re-assessment', British Journal of Political Science 17: 281-313.

Scott, P. (2004) 'Regional policy', in: R. Floud and P. Johnson (eds.) The Cambridge Economic History of Britain, Vol 3, Structural Change and Growth, 1939-2000, Cambridge: Cambridge University Press, pp. 332-367.

Stephens, P. (1996) Politics and the Pound, London: Macmillan. 
Thain, C. (1985) 'The education of the Treasury: the medium term financial strategy 1980-84', Public Administration 63: 261-285.

Thain, C. and Wright, M. (1995) The Treasury and Whitehall: the Planning and Control of Public Expenditure, 1976-1993, Oxford: Clarendon.

Thatcher, M. (1993) The Downing Street Years, London: Harper Collins.

Thompson, H. (1996) The British Conservative Government and the European Exchange Rate Mechanism 1979-1994, London: Pinter.

Tomlinson, J. (1990) Public Policy and the Economy since 1900, Oxford: Oxford University Press.

Tomlinson, J. (2000) The Politics of Decline: Understanding Post-War Britain, Harlow: Pearson.

Tomlinson, J. (2007) 'Tale of a death exaggerated: how Keynesianism survived the 1970s", Contemporary British History, forthcoming.

Townsend, A. (1983) The Impact of Recession, London: Croom Helm.

Treasury and Civil Service Committee (1980) Memoranda on Monetary Policy, HCP 720.

Treasury and Civil Service Committee (1981a) Monetary Policy Volume I. Report House of Commons Papers, 163-I.

Treasury and Civil Service Committee (1981b) Monetary Policy Volume II. Minutes of Evidence, HCP 163-II.

Walters, A. (1986) Britain's Economic Renaissance, Oxford: Oxford University Press.

Whiteley, P. (1983) 'Perceptions of economic performance and voting behaviour in the 1983 general election in Britain', Political Behaviour 6(4): 395-410.

Wickham-Jones, M. (1992) 'Monetarism and its critics: the universities economists protest of 1981', Political Quarterly 63(2): 171-185.

Wood, J. (1975) How Little Unemployment?, London: Institute of Economic Affairs. 